\title{
PENGEMBANGAN PROGRAM PEMBELAJARAN FISIKA SMA BERBANTUAN KOMPUTER
}

\author{
Oleb: \\ Titi Wurdiyanti
}

\begin{abstract}
Abstrak
Secara umum, penelitian ini bertujuan untuk mengembang-kan program pembelajaran fisika sekolah menengah atas berbantuan komputer dan kemudian mengevaluasi program tersebut pada sampel siswa dari populasi penelitian ini. Secara lebih luas, tujuan penelitian ini adalah: (1) mempelajari tanggapan siswa terhadap program tersebut, dan (2) mempelajari perbedaan antara prestasi hasil belajar siswa sebelum dan sesudah mereka menggunakan program tersebut (perbedaan antara skor pretest dan skor post test).

Subjek uji coba meliputi 82 orang, terdiri atas seorang ahli mata pelajaran, seorang ahli media, 30 siswa untuk uji coba instrumen penelitian, 20 siswa untuk uji coba kelompok kecil, dan 30 siswa untuk uji coba lapangan. Data penelitian ini dikumpulkan menggunakan angket pembelajaran dan tes fisika (tes awal dan tes akhir). Evaluasi program dilakukan berdasarkan aspek pembelajaran dan media. Kritik dan saran dari responden digunakan untuk meningkatkan program tersebut.

Temuan penelitian menunjukkan bahwa dari aspek pembelajaran dan media, program pembelajaran fisika sekolah menengah atas berbantuan komputer secara keseluruhan menarik, bisa meningkatkan motivasi belajar (diberi nilai B oleh responden), dan meningkatkan nilai rata-rata siswa $18 \%$.
\end{abstract}

Kata Kunci: pengembangan program, model pengembangan, validasi program. 


\section{Pendahuluan}

Menggarisbawahi pandangan Dwyer (1978) bahwa perkembangan optimal seorang manusia tergantung pada kemampuannya untuk belajar dan berkomunikasi. Meskipun bentuk komunikasi paling umum adalah dengan kata-kata yang diucapkan. Kesalahan interpretasi seringkali terjadi saat seseorang berusaha untuk mengkomunikasikan ide-ide tertentu kepada orang lain. Fakta bahwa kata-kata seringkali gagal mengkomunikasikan pesan yang diinginkan secara tepat, memperkuat anggapan bahwa proses penggunaan kata-kata atau simbol-simbol verbal dalam proses pembelajaran/komunikasi sangat rumit dan merupakan metode yang tidak terpercaya dalam penyampaian informasi. Tidak terpercaya dalam konteks bahwa jika individu/siswa sebagai satu kesatuan tidak memiliki pengalaman yang sama, maka individu tidak akan bisa memiliki arti/pemahaman yang sama untuk sebuah benda yang disimbolkan.

Fakta tersebut telah dibuktikan berulang-ulang oleh para guru bahwa, sesaat setelah menerima pelajaran, diberikan kuis/pertanyaan menyangkut informasi yang disampaikan dalam pelajaran. Beragamnya nilai yang diperoleh dalam kuis menunjukkan, bahwa ada perbedaan dalam hal jumlah informasi yang diperoleh oleh masing-masing siswa melalui metode ceramah. Artinya, meskipun semua siswa di kelas mendapatkan pelajaran yang sama mengenai suatu topik misalnya, maka hanya beberapa persen saja siswa yang benar-benar mendapatkan pesan asli dengan arti yang dikehendaki oleh guru (100\%). Para siswa yang menerima informasi yang sama memperoleh berbagai macam pesan/ informasi yang berbeda, mungkin $60 \%, 70 \%$ atau dibawah $50 \%$.

Oleh karena itu, dalam rangka meningkatkan kejelasan dan memudahkan pemahaman atau pembelajaran siswa terhadap informasi yang disampaikan, khususnya dalam mata pelajaran fisika di Sekolah Menengah Atas (SMA) dan untuk mengakomodir latar belakang pengalaman belajar siswa yang tidak sama, maka strategi/metode yang dirasa tepat adalah dengan menggunakan materi visual. Media visualnya bisa bermacam-macam. Tetapi fokus pada penelitian ini adalah materi visual yang ditayangkan dengan bantuan komputer.

Terkait dengan hal tersebut, supaya metode pembelajaran fisika berbantuan komputer (PBK) dapat berlangsung maka diperlukan suatu pro- 
gram (software) pembelajaran. Supaya metode PBK efektif, diperlukan program (software) yang baik yang mutunya telah teruji. Namun, berdasarkan pengamatan langsung di lapangan, ditemukan bahwa, program (software) pembelajaran yang notabene merupakan sumber belajar yang dirancang (by designed) untuk mata pelajaran fisika masih sangat terbatas ketersediaannya, apalagi program (software) pembelajaran fisika yang dibuat dengan berbagai tahapan validasi atau ujicoba dan berbasis kurikulum. Dari hasil wawancara peneliti dengan beberapa guru fisika secara informal, hal tersebut disebabkan pada umumnya untuk mencoba membuat sendiri program (software) pembelajarannya, para guru terjegal oleh sumber daya guru yang masih minimal, yakni pemahaman mengenai authoring system, authoring tool, pemrograman komputer maupun sumber daya yang lainnya.

Ada tiga tahapan dalam penelitian pengembangan program pembelajaran fisika SMA berbantuan komputer ini, yaitu diawali dengan tahap desain, tahap pembuatan/produksi, dan tahap validasi/evaluasi. Authoring tool yang digunakan adalah Macromedia Flash $M X 2004$, software aplikasi komputer berbasis vektor terpilih untuk saat ini. Produk finalnya dikemas atau disimpan dalam bentuk $\mathrm{CD}$ (compact disc).

Ada beberapa manfaat dari materi yang ditayangkan dengan bantuan komputer yang bisa diketahui terutama pada saat perubahannya dari sekedar materi tambahan, menjadi materi yang terintegrasi dalam sebuah proses pembelajaran dengan format baru. Andersen \& Koutnik (1972:136-138), begitu juga Kemp (1975:6) mengeluarkan pernyataan hampir senada, dan menguraikan manfaat-manfaat tersebut menjadi lima, yaitu: (1) membuat pendidikan lebih efektif, (2) membuat pendidikan menjadi lebih individualis, (3) membuat pelajaran lebih cepat, (4) membuat akses pendidikan lebih merata untuk siswa, dan (5) memberikan pembelajaran lebih ilmiah dengan menyediakan framework untuk perencanaan pembelajaran yang sistematis.

Lebih jauh Kulik. Bangert \& Williams, (1983) menyatakan:

Among the benefits expected for learner where better, more confortable, and faster learning, since students would learn at their oum pace and at their own convenience; opportunities to work with vastly richer material and more sophisticated problems; 


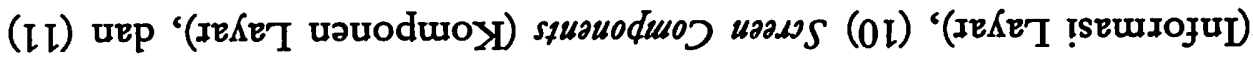

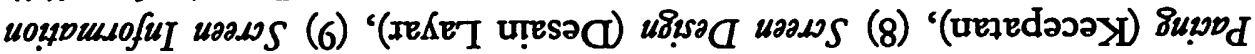

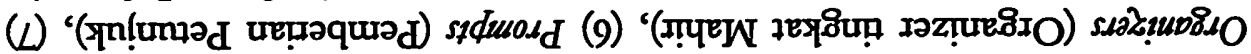

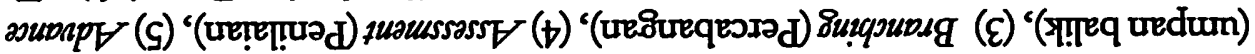

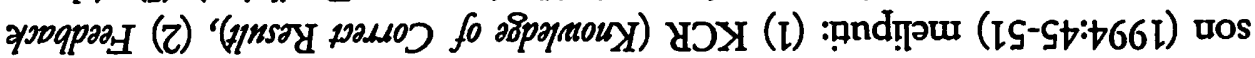

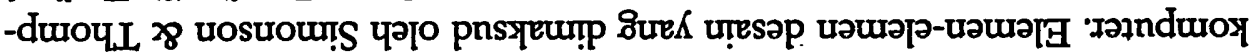
urnureq

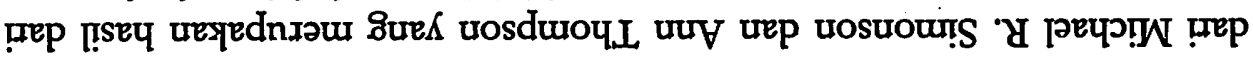

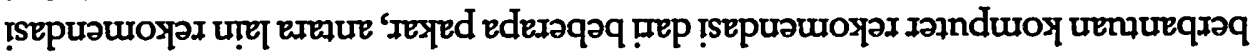
uеIele

"นouppiusu

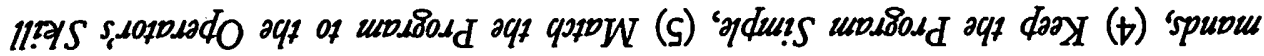

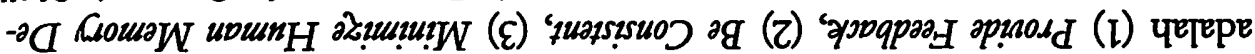

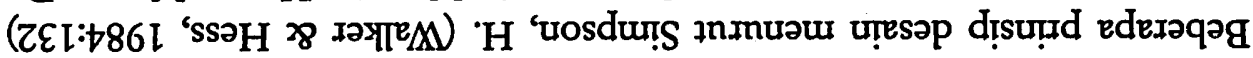

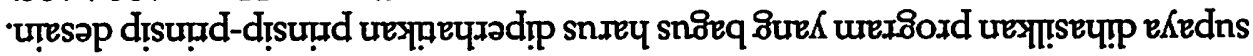

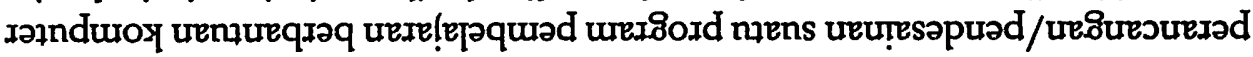

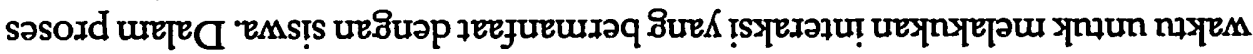



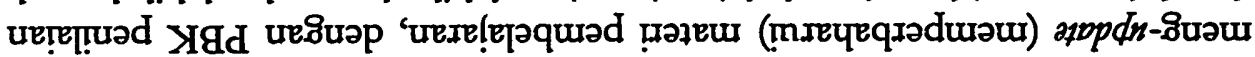

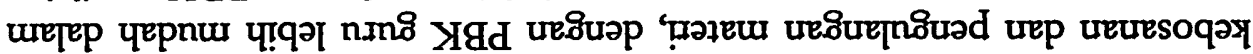

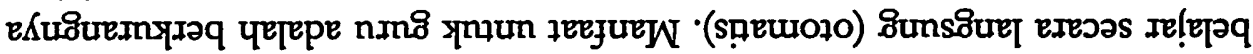

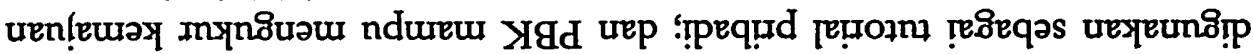


ге!е|ә ‡nภnuวu relep

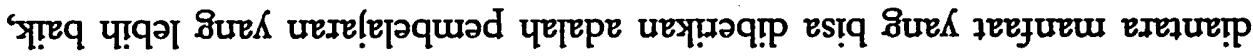

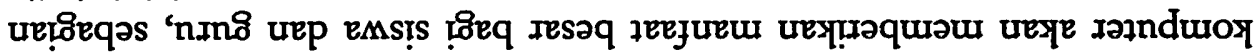





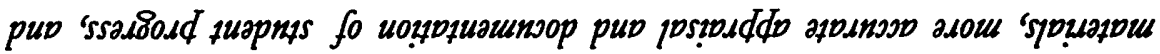

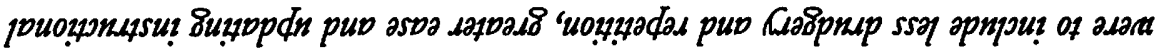

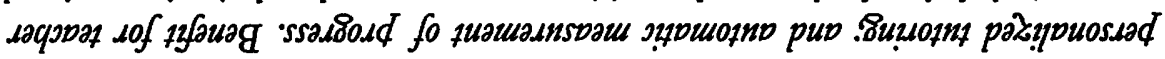


Keterbacaan (Readability).

Selain desain layar yang direkomendasikan oleh Simonson \& Thompson di atas ada juga desain layar (screen design) yang ditulis oleh beberapa pakar antara lain, Linda Tway. Linda Tway (Sutopo, 2003:43) mengatakan bahwa terdapat beberapa aspek penting pada desain layar, terutama informasi yang ditampilkan pada screen harus teratur, dan ada beberapa hal yang harus diperhatikan yaitu: (1) Tidak boleh melebihi tiga window dalam satu screen, (2) Kecepatan tampilan harus diperhatikan, (3) Tidak boleh menampilkan banyak teks pada satu screen, (4) Tampilan dari awal hingga akhir harus konsisten, tombol (button) diletakkan sedemikian rupa, sehingga user mudah memahami isi dari tampilan secara keseluruhan.

Elemen-elemen visual dan verbal yang dimaksud meliputi: letter style, number of lettering styles, capitals, color of lettering, size of lettering, spacing between letters, spacing between lines. Ada elemen yang dapat menambah daya tarik meliputi: kejutan, tekstur, dan interaksi. Sedangkan yang termasuk pola (pattern) meliputi: perataan, bentuk, keseimbangan, gaya, skema warna, dan daya tarik warna. Yang termasuk penyusunan (arrangement) meliputi: skala kedekatan (proximity), arah (directionals), kekontrasan gambar dengan background, dan konsistensi.

\section{Metode Penelitian}

\section{Model Pengembangan}

Terlepas dari banyaknya model yang ditemukan peneliti, pada dasarnya substansinya sama, yaitu bagaimana membuat program pembelajaran berbantuan komputer yang bermutu untuk tujuan pembelajaran yang efektif dan efisien. Hanya istilah dan namanya saja, (dari elemen-elemen model tersebut) yang berbeda. Untuk tujuan memudahkan pemahaman dan persepsi tentang elemen-elemen berbagai model, dan setelah melalui analisa yang mendalam maka diputuskan untuk tidak menggunakan model tunggal tetapi lebih baik menggunakan kombinasi dari beberapa model, dengan beberapa pemadatan dan pemekaran disana-sini oleh peneliti sendiri. Model pengembangan penelitian ini adalah: 


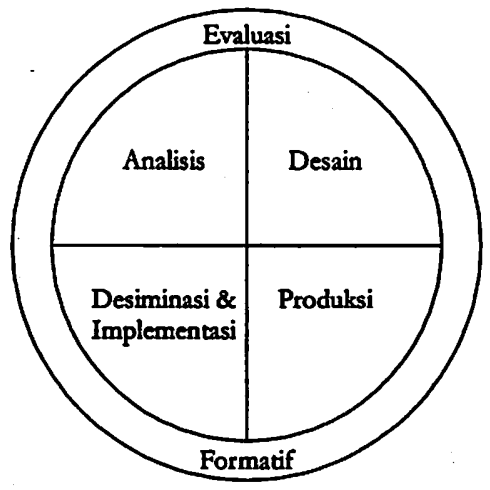

Gambar 1.

Model Pengembangan Program Pembelajaran Berbantuan Komputer (Diapdatasi dari Model Luther (Sutopo, 2003); Fresen (1996); Prata \& Lopes (2004); Agnew, et al. (1996); Criswell (1989); Andersen \& Koutnik (1972); Sadiman, dkk. (1986); dan Kemp \& Dayton (1985))

Elemen-elemen Model Pengembangan pada gambar diatas dapat dijelaskan sebagai berikut:

\section{Analisis}

Pada tahap analisis ini ada dua tahapan yaitu diawali dengan analisis keberlangsungan (Viability Analysis) dan analisis kebutuhan (Necessities Analysis).

Pada analisis keberlangsungan:

Tujuannya adalah menganalisa keberlangsungan pengembangan program ini kedepan (prospek masa depan). Sebagai inputnya adalah kebutuhankebutuhan siswa dan guru. Tugas/kegiatannya adalah menjelaskan (tidak terlalu detil), tujuan; pemililihan media; analisis tugas; sumber hambatan dan biaya; pengembangan strategi penerapan alternatif. Outputnya adalah laporan keberlangsungan yang akan menunjukkan jalan-jalan alternatif. 
Pada analisis kebutuhan:

Tujuannya adalah mendeskripsikan situasi dan tujuan pembelajaran. Inputnya adalah kebutuhan awal yang diidentifikasi dalam laporan keberlangsungan. Tugasnya adalah menjelaskan secara detil mengenai: survey kondisi lapangan; deskripsi populasi target (pengetahuan, motivasi, kemampuan, tujuan) dan pemilihan kelompok evaluasi; analisis kebutuhan pembelajaran dan tingkatan tujuan pembelajaran; analisis subyek penelitian, dan deskripsi masalah pemilihan tujuan dan komponen umum; pemilihan model pembelajaran dan model pengembangan program/multimedia, pemilihan macam aplikasi multimedia yang akan dikembangkan (dipilih multimedia interaktif), memutuskan menggunakan Macromedia Flash $M X$ 2004, Flash versi yang terbaru sebagai authoring tool. Termasuk dasar-dasar aturan untuk perancangan, misalnya dicari ukuran aplikasi yang hemat tempat, supaya bisa di up-load ke internet, dapat digunakan untuk e-learning tidak cuma untuk pembelajaran off line saja, dan lain-lain. Outputnya adalah spesifikasi kebutuhan; ketetapan materi/isi pembelajaran fisika; ketetapan model/silabus pembelajaran fisika; dan model pengembangan program/multimedia.

\section{Desain}

Pada tahap desain (perancangan) ini seluruh spesifikasi mengenai arsitektur, gaya, dan kebutuhan material, untuk proyek pembuatan program pembelajaran dibuat. Spesifikasi dibuat cukup rinci disini, supaya pada tahap berikutnya, yaitu tahap produksi dan atau assembly tidak dibuat keputusankeputusan baru sehingga tidak terjadi pemekaran waktu dari jadwal waktu yang telah ditetapkan.

\section{Produksi}

Pada tahap ini seluruh objek multimedia dibuat dan atau di assembly/ dirangkai. Pada tahap produksi ini dibagi menjadi tiga yaitu:

1) Pembuatan dan pengumpulan komponen

Tujuannya adalah membuat dan mengumpulkan semua komponen yang digunakan. Sebagai inputnya adalah spesifikasi fungsi yang telah dibuat pada 
tahap sebelumnya. Tugas/kegiatannya adalah pengetikan materi fisika dalam format word; mengumpulkan image, button, dan clip-art, sound, musik pengiring, video, dan lain-lain dari library atau sumber yang lain; membuat sendiri buttonbutton yang diperlukan, image dan obyek-obyek untuk animasi, dengan menggunakan tool-tool pendukung (Adobe Pbotoshop, Swift 3D) dan dengan Flash itu sendiri. Outputnya adalah semua komponen multimedia yang akan digunakan, dan naskah materi fisika dalam format word.

2) Penyatuan komponen

Tujuannya adalah mengintegrasikan semua komponen ke dalam screen. Sebagai input adalah spesifikasi fungsi dan semua komponen yang akan digunakan dan telah dipersiapkan pada tahap sebelumnya. Tugas/kegiatannya adalah menstransfer materi fisika dalam format word ke dalam stage Flash, mendistribusikan materi fisika kedalam screen seperti apa yang terdapat dalam flowchart dan lay-out, penyatuan semua komponen yang dikumpulkan atau dibuat; membuat animasi; membuat bahasa pemrograman untuk menjalankan animasi; mengintegrasikan video (format .avr) ke dalam movie Flash; membuat bahasa pemrograman untuk me-load video; mengintegrasikan sound ke dalam button, mengintegrasikan sound kedalam animasi, dan lain-lain. Output pada tahap ini adalah produk awal.

3) Testing Prototipe/produk awal.

Tujuannya adalah mengetes produk awal, mengevaluasi, dan mengidentifikasi kekurangan-kekurangannya. Sebagai input pada tahap ini adalah produk awal. Tugas/kegiatannya adalah pemasangan produk awal dan mengevaluasinya untuk mendeteksi masalah-masalah dan mengevaluasi efektivitas dan efisiensinya; merevisi kekurangan-kekurangan program berdasarkan data dari ahli materi dan ahli media serta data dari tanggapan subyek/siswa. Output berakhir pada evaluasi produk awal.

\section{Evaluasi Formatif}

Evaluasi formatif dilakukan terus menerus sepanjang proses pengembangan. Uraian tentang evaluasi formatif ini akan dirinci secara detil pada prosedur pengembangan di bawah ini. Tujuan terakhir evaluasi ini adalah 
mendapatkan produk akhir yang siap diimplementasikan dan dideseminasikan secara luas di lapangan. Esensi kegiatan evaluasi ini adalah mencari tanggapan dari subyek ujicoba terhadap program pembelajaran berbantuan komputer yang telah dikembangkan.

5. Diseminasi \& Implementasi

Pada tahap ini, produk akhir disebarluaskan kepada populasi target yang membutuhkan.

\section{Prosedur Pengembangan}

Prosedur pengembangan ini sebagian di adaptasi dari cara-cara Borg \& Gall (1983:772-787). Khusus prosedur evaluasi formatif program, dominan diadaptasi dari cara-cara Sadiman dkk (1986:174-179). Dengan alasan karena prosedur evaluasi program dari Sadiman dkk ini merupakan prosedur evaluasi yang lebih sederhana dan masuk akal (mudah dilaksanakan).

Tahap pertama dan terakhir dari model pengembangan diatas, tidak dimasukkan kedalam prosedur pengembangan ini. Prosedur penelitian ini meliputi tahap Desain, tahap Produksi, dan tahap Evaluasi Formatif.

\section{Ujicoba Produk}

Ujicoba produk ini dimaksudkan untuk mengumpulkan data tentang kualitas program untuk mencapai tujuan pembelajaran fisika yang efektif. Datadata tersebut dipergunakan untuk memperbaiki dan menyempurna-kan program pembelajaran fisika berbantuan komputer yang merupakan produk penelitian ini. Dengan ujicoba ini kualitas program pembelajaran yang dikembangkan benar-benar telah teruji secara empiris tidak hanya secara teoritis saja.

1. Desain Ujicoba

Ada tiga tahapan ujicoba/validasi program pembelajaran fisika berbantuan komputer dalam penelitian ini. Ketiga tahapan tersebut adalah: 
1) Evaluasi Satu Lawan Satu (one-to-one)

Pada tahap ini telah dipilih satu orang ahli media (media specialist) dan satu orang ahli materi fisika SMA (content expert) untuk me-review program/produk awal. Kegiatan ini dilaksanakan di Laboratorium Fisika Universitas Negeri Yogyakarta.

2) Evaluasi Kelompok Kecil (small-group evaluation)

Pada tahap ini produk/program pembelajaran fisika dicobakan kepada kelompok kecil terdiri dari 20 orang siswa. Prosedur yang ditempuh dalam ujicoba kelompok kecil pada penelitian ini sebagian besar mengikuti langkahlangkah yang diberikan oleh Sadiman dkk (1986:177) dan Bhattacharya, Akahori, \& Kumar (1999) sebagai berikut: (a) Melakukan pengkopian/ pemasangan program PBK ke dalam komputer server di laboratorium SMA Negeri 1 Bontang, untuk di share oleh 20 komputer workstation yang ada di dalam laboratorium tersebut; (b) Melakukan pengkopian dan penyimpanan ke harddisk masing-masing komputer workstation.

3) Evaluasi Lapangan (field evaluation)

Tahap ini merupakan tahap akhir evaluasi formatif yang dilakukan pada penelitian ini. Produk yang telah direvisi dicobakan kembali kepada 30 orang siswa yang lain, yang mewakili populasi target. Setting lingkungan dibuat persis dengan situasi pembelajaran sebenarnya di lapangan. Prosedur yang ditempuh dalam rangka ujicoba lapangan ini sama dengan langkahlangkah pada ujicoba kelompok kecil.

\section{Subyek Coba}

Subyek coba penelitian ini adalah siswa kelas X D Semester 1, SMA Yayasan Pupuk Kaltim Bontang, siswa kelas X C dan X D Semester 1 SMA Negeri 1 Bontang, Propinsi Kalimantan Timur tahun Pembelajaran 2004/ 2005. Subyek coba keseluruhan berjumlah 80 orang siswa dan 2 orang ahli, dengan perincian sebagai berikut:

1) Kelas X D SMA Yayasan Pupuk Kaltim Bontang berjumlah 30 orang siswa dipergunakan sebagai subyek validasi instrumen penelitian. 
2) Kelas X C SMA 1 Bontang, diambil 20 orang siswa dari 30 siswa yang tersedia, diambil dengan cara undian, dipergunakan sebagai subyek coba kelompok kecil.

3) Kelas XD SMA 1 Bontang, berjumlah 30 orang siswa dipergunakan sebagai subyek coba lapangan.

Sedangkan dua ahli yaitu satu ahli media (media specialist) dan dan satu ahli materi/isi (content expert).

\section{Jenis Data}

Seperti telah diuraikan pada bab sebelumnya bahwa tujuan penelitian ini adalah untuk mengetahui tanggapan siswa mengenai kualitas program pembelajaran fisika berbantuan komputer yang dipertunjukkan kepadanya, jadi variabel yang diukur adalah kualitas program PBK. Untuk keperluan ini maka data yang dijaring berupa data kuantitatif dan kualitatif yang berupa tanggapan-tanggapan, kritik, dan saran siswa serta evaluasi para ahli mengenai kualitas program tersebut.

Kriteria penilaian hasil kuesioner tanggapan siswa menggunakan cara sebagai berikut:

Data yang diperoleh dari kuesioner tanggapan siswa diubah menjadi data interval sebagai berikut:

$\begin{array}{ll}\text { Sangat Bagus (SB) } & =5 \\ \text { Bagus (B) } & =4 \\ \text { Cukup (C) } & =3 \\ \text { Kurang (K) } & =2 \\ \text { Sangat Kurang (SK) } & =1\end{array}$

Kemudian skor yang didapat dikonversikan menjadi nilai, pada skala 5 . Dengan acuan tabel konversi berikut: 
Tabel 1.

Konversi Skor ke Nilai pada Skala 5

\begin{tabular}{|c|c|c|}
\hline Nilai & Kategori & Interval Skor \\
\hline A & Sangat Tinggi & $\mathrm{X}>$ \\
B & Tinggi & $\overline{X_{i}}+0,60 S B_{i}<\mathrm{x}$ \\
C & Sedang & $\overline{X_{i}}-0,60 S B_{i}<\mathrm{x}$ \\
$\mathrm{D}$ & Kurang & $<\mathrm{x}$ \\
$\mathrm{E}$ & Sangat Kurang & $\mathrm{x}$ \\
\hline
\end{tabular}

Dengan berpedoman kepada tabel konversi skor ke nilai (pada skala 5) maka didapatkan nilai Produk Program Pembelajaran Fisika Berbantuan Komputer.

\section{Instrumen Pengumpul Data}

Instrumen yang digunakan untuk mengumpulkan data pada penelitian ini berupa kuesioner dan tes fisika. Instrumen berupa kuesioner disusun untuk maksud mengevaluasi kualitas program PBK dan instrumen berupa tes fisika disusun untuk maksud mengetahui seberapa jauh tujuan-tujuan belajar dengan menggunakan program telah tercapai.

\section{Teknik Analisis Data}

Data mengenai pendapat/tanggapan siswa/responden yang dikumpulkan melalui kuesioner dianalisis secara statistik deskriptif dengan bantuan program SPSS Version 11.0. Kritik dan saran kongkrit yang dikemukakan responden, dihimpun dan disarikan untuk memperbaiki program pembelajaran fisika berbantuan komputer.

Data mengenai perbedaan rerata skor pretest dan posttest dianalisis dengan matematika biasa. 


\section{Hasil Penelitian}

Tabel 2

Persentase Respon/Tanggapan Siswa Terhadap Program PBK Pada Materi Gerak Lurus*)

\begin{tabular}{|c|c|c|c|c|c|c|}
\hline \multirow[t]{3}{*}{ No. } & \multirow[t]{3}{*}{ Pernyataan } & \multicolumn{5}{|c|}{ Persentase Respon } \\
\hline & & $\begin{array}{l}\text { Sangat } \\
\text { Kurang }\end{array}$ & Kurang & Cukup & Bagus & $\begin{array}{l}\text { Sangat } \\
\text { Bagus }\end{array}$ \\
\hline & & 1 & 2 & 3 & 4 & 5 \\
\hline 01 & Kejelasan petunjuk penggunaan & 0 & 0 & مח & 500 & 300 \\
\hline 02 & Keterbacaan teks/tulisan & 3,3 & 26,7 & $\begin{array}{l}20,0 \\
33,3\end{array}$ & $\begin{array}{l}50,0 \\
30,0\end{array}$ & $\begin{array}{l}30,0 \\
6,7\end{array}$ \\
\hline 03 & Kualitas tampilan gambar & 0 & 3,3 & 23,3 & 40,0 & 33,3 \\
\hline 04 & Sajian animasi & 0 & 6,7 & 23,3 & 26,7 & 43,3 \\
\hline 05 & Komposisi warna & 0 & 13,3 & 26,7 & 36,7 & 23,3 \\
\hline 06 & Kejelasan suara/narasi & 3,3 & 10,0 & 30,0 & 50,0 & 6,7 \\
\hline 07 & Daya dukung musik & 10,0 & 26,7 & 23,3 & 26,7 & 13,3 \\
\hline 08 & Navigasi & 0 & 0 & 20,0 & 46,7 & 33,3 \\
\hline 09 & Kejelasan standar kompetensi \& & & & & & \\
\hline & kompetensi dasar & 0 & 0 & 36,7 & 43,3 & 20,0 \\
\hline 10 & Kejelasan petunjuk belajar & 0 & 6,7 & 30,0 & 46,7 & 16,7 \\
\hline 11 & Kemudahan memahami kalimat & & & & & \\
\hline & pada teks/tulisan & 0 & 20,0 & 56,7 & 13,3 & 10,0 \\
\hline 12 & $\begin{array}{l}\text { Kemudahan memahami materi/ } \\
\text { isi pelajaran }\end{array}$ & 0 & 20,0 & 43,3 & 26,7 & 10,0 \\
\hline 13 & Ketepatan urutan penyajian & 0 & 0 & 26,7 & 53,3 & 20,0 \\
\hline 14 & Kecukupan latihan & 6,7 & 36,7 & 30,0 & 20,0 & 6,7 \\
\hline 15 & Interaktivitas & 6,7 & 3,3 & 33,3 & 40,0 & 16,7 \\
\hline 16 & Kejelasan umpan balik/respon & 0 & 23,3 & 23,3 & 40,0 & 13,3 \\
\hline 17 & Bantuan belajar dengan program ini & 0 & 0 & 13,3 & 50,0 & 36,7 \\
\hline
\end{tabular}


Tabel 3

Persentase Respon/Tanggapan Siswa Terhadap Program PBK Pada Materi Gerak Melingkar*)

\begin{tabular}{|c|c|c|c|c|c|c|}
\hline \multirow[t]{3}{*}{ No. } & \multirow[t]{3}{*}{ Pernyataan } & \multicolumn{5}{|c|}{ Persentase Respon } \\
\hline & & $\begin{array}{l}\text { Sangat } \\
\text { Kurang }\end{array}$ & Kurang & Cukup & Bagus & $\begin{array}{l}\text { Sangat } \\
\text { Bagus }\end{array}$ \\
\hline & & 1 & 2 & 3 & 4 & 5 \\
\hline 01 & $\begin{array}{l}\text { Kejelasan petunjuk penggunaan } \\
\text { program }\end{array}$ & & & & & \\
\hline 02 & $\begin{array}{l}\text { program } \\
\text { Keterbacaan teks/tulisan }\end{array}$ & 0 & 0 & 20,0 & 53,3 & 26,7 \\
\hline 03 & Kualitas tampilan gambar & 0 & 3,3 & 13,3 & 53,3 & 30,0 \\
\hline 04 & Sajian animasi & 0 & 3,3 & 30,0 & 43,3 & 23,3 \\
\hline 05 & $\begin{array}{l}\text { Sajian animasi } \\
\text { Komposisi warna }\end{array}$ & 0 & 3,3 & 30,0 & 36,7 & 30,0 \\
\hline 06 & & 0 & 0 & 23,3 & 53,3 & 23,3 \\
\hline 07 & $\begin{array}{l}\text { Kejelasan suara/narasi } \\
\text { Dava dukung musik }\end{array}$ & 0 & 3,3 & 20,0 & 56,7 & 20,0 \\
\hline & Daya dukung musik & 0 & 23,3 & 33,3 & 23,3 & 20,0 \\
\hline 08 & Navigasi & 0 & 0 & 10,0 & 60,0 & 30,0 \\
\hline 09 & Kejelasan standar kompetensi \& & & & & & \\
\hline & kompetensi dasar & 0 & 0 & 16,7 & 63,3 & 20,0 \\
\hline 10 & Kejelasan petunjuk belajar & 0 & 0 & 16,7 & 60,0 & 23,3 \\
\hline 11 & $\begin{array}{l}\text { Kemudahan memahami kalimat } \\
\text { pada teks/tulisan }\end{array}$ & 0 & 67 & 433 & 300 & \\
\hline 12 & Kemudahan memahami materi/ & & 0,1 & 43,3 & 30,0 & 20,0 \\
\hline & isi pelajaran & 0 & 3,3 & 40,0 & 40,0 & 16,7 \\
\hline 13 & Ketepatan urutan penyajian & 0 & 0 & 10,0 & 70,0 & 20,0 \\
\hline 14 & Kecukupan latihan & 0 & 20,0 & 40,0 & 23,3 & 16,7 \\
\hline 15 & Interaktivitas & 0 & 0 & 23,3 & 56,7 & 20,0 \\
\hline 16 & Kejelasan umpan balik/respon & 0 & 0 & 26,7 & 53,3 & 20,0 \\
\hline 17 & Bantuan belajar dengan program ini & 0 & 0 & 23,3 & 43,3 & 33,3 \\
\hline & Komentar dan Saran: & & & & & \\
\hline
\end{tabular}


Tabel 4

Persentase Respon/Tanggapan Siswa Terhadap Program PBK Pada Materi Dinamika Partikel*)

\begin{tabular}{|c|c|c|c|c|c|c|}
\hline \multirow[t]{3}{*}{ No. } & \multirow[t]{3}{*}{ Pernyataan } & \multicolumn{5}{|c|}{ Persentase Respon } \\
\hline & & $\begin{array}{l}\text { Sangat } \\
\text { Kurang }\end{array}$ & Kurang & Cukup & Bagus & $\begin{array}{l}\text { Sangat } \\
\text { Bagus }\end{array}$ \\
\hline & & 1 & 2 & 3 & 4 & 5 \\
\hline 01 & $\begin{array}{l}\text { Kejelasan petunjuk penggunaan } \\
\text { program }\end{array}$ & 0 & 0 & 10,0 & 63,3 & 26,7 \\
\hline 02 & Keterbacaan teks/tulisan & 0 & 3,3 & 16,7 & 50,0 & 30,0 \\
\hline 03 & Kualitas tampilan gambar & 0 & 3,3 & 13,3 & 50,0 & 33,3 \\
\hline 04 & Sajian animasi & 0 & 3,3 & 16,7 & 33,3 & 46,7 \\
\hline 05 & Komposisi warna & 0 & 0 & 30,0 & 40,0 & 30,0 \\
\hline 06 & Kejelasan suara/narasi & 0 & 6,7 & 20,0 & 53,3 & 20,0 \\
\hline 07 & Daya dukung musik & 3,3 & 20,0 & 33,3 & 26,7 & 16,7 \\
\hline 08 & Navigasi & 0 & 3,3 & 26,7 & 53,3 & 16,7 \\
\hline 09 & Kejelasan standar kompetensi \& & & & & & \\
\hline & kompetensi dasar & 0 & 0 & 16,7 & 63,3 & 20,0 \\
\hline 10 & Kejelasan petunjuk belajar & 0 & 0 & 13,3 & 60,0 & 26,7 \\
\hline 11 & Kemudahan memahami kalimat & & & & & \\
\hline & pada teks/tulisan & 0 & 6,7 & 36,7 & 40,0 & 16,7 \\
\hline 12 & $\begin{array}{l}\text { Kemudahan memahami materi/ } \\
\text { isi pelajaran }\end{array}$ & 0 & 0 & 43,3 & 40,0 & 16,7 \\
\hline 13 & Ketepatan urutan penyajian & 0 & 0 & 16,7 & 63,3 & 20,0 \\
\hline 14 & Kecukupan latihan & 0 & 20,0 & 30,0 & 33,3 & 16,7 \\
\hline 15 & Interaktivitas & 0 & 0 & 16,7 & 60,0 & 23,3 \\
\hline 16 & Kejelasan umpan balik/respon & 0 & 0 & 26,7 & 50,0 & 23,3 \\
\hline 17 & Bantuan belajar dengan program ini & 0 & 0 & 20,0 & 40,0 & 40,0 \\
\hline & Komentar dan saran & & & & & \\
\hline
\end{tabular}




\section{Tabel 5}

Data Persentase Pencapaian Pretest dan Posttest Fisika

\begin{tabular}{|c|c|c|c|c|c|c|c|c|}
\hline \multirow{2}{*}{$\begin{array}{c}\text { No. Urut } \\
\text { Siswa }\end{array}$} & \multicolumn{2}{|c|}{$\begin{array}{c}\text { Materi } \\
\text { Gerak Lurus }\end{array}$} & \multicolumn{2}{|c|}{$\begin{array}{c}\text { Materi Gerak } \\
\text { Melingkar }\end{array}$} & \multicolumn{2}{|c|}{$\begin{array}{c}\text { Materi Dinamika } \\
\text { Partikel }\end{array}$} & $\begin{array}{c}\text { Rerata } \\
\text { Pretest }\end{array}$ & $\begin{array}{l}\text { Rerata } \\
\text { Posttest }\end{array}$ \\
\cline { 2 - 7 } & Pretest & Posttest & Pretest & Posttest & Pretest & Posttest & & \\
\hline 1 & 50 & 57 & 40 & 60 & 57 & 93 & 49 & 70 \\
2 & 57 & 57 & 32 & 40 & 30 & 63 & 40 & 53 \\
3 & 57 & 57 & 24 & 56 & 47 & 83 & 43 & 59 \\
4 & 57 & 50 & 28 & 52 & 40 & 80 & 42 & 61 \\
5 & 43 & 50 & 36 & 68 & 70 & 87 & 50 & 68 \\
6 & 64 & 64 & 40 & 88 & 87 & 93 & 64 & 82 \\
7 & 50 & 50 & 52 & 76 & 57 & 93 & 53 & 73 \\
8 & 71 & 86 & 48 & 80 & 67 & 93 & 62 & 86 \\
9 & 43 & 57 & 44 & 76 & 50 & 63 & 46 & 65 \\
10 & 50 & 57 & 48 & 72 & 67 & 70 & 55 & 66 \\
11 & 57 & 64 & 56 & 76 & 83 & 100 & 65 & 80 \\
12 & 64 & 71 & 36 & 72 & 60 & 93 & 53 & 79 \\
13 & 64 & 64 & 40 & 60 & 57 & 97 & 54 & 74 \\
14 & 36 & 50 & 24 & 68 & 53 & 90 & 38 & 69 \\
15 & 50 & 64 & 84 & 80 & 57 & 93 & 64 & 79 \\
16 & 43 & 50 & 28 & 36 & 50 & 83 & 40 & 56 \\
17 & 57 & 50 & 76 & 56 & 67 & 90 & 67 & 65 \\
18 & 57 & 79 & 56 & 68 & 63 & 93 & 59 & 80 \\
19 & 57 & 64 & 52 & 44 & 50 & 77 & 53 & 62 \\
20 & 64 & 71 & 52 & 88 & 63 & 87 & 60 & 82 \\
21 & 36 & 57 & 72 & 88 & 67 & 100 & 58 & 82 \\
22 & 50 & 50 & 72 & 80 & 73 & 63 & 65 & 64 \\
23 & 36 & 50 & 40 & 84 & 60 & 77 & 45 & 70 \\
24 & 64 & 71 & 68 & 68 & 50 & 90 & 61 & 76 \\
25 & 57 & 57 & 40 & 92 & 40 & 77 & 46 & 75 \\
26 & 43 & 57 & 44 & 60 & 43 & 37 & 43 & 51 \\
27 & 64 & 79 & 56 & 76 & 63 & 80 & 61 & 78 \\
28 & 43 & 43 & 12 & 44 & 37 & 67 & 31 & 51 \\
29 & 50 & 57 & 28 & 64 & 47 & 70 & 42 & 64 \\
30 & 43 & 64 & 44 & 80 & 53 & 77 & 47 & 74 \\
\hline Rerata & 53 & 60 & 46 & 68 & 57 & 81 & 52 & 70 \\
\hline & & & & & & &
\end{tabular}




\begin{tabular}{|c|c|c|c|c|c|c|}
\hline ழீఠిరి!ు & & $q$ &  & ழீ8ిน!ు & फீ8ిర!! & 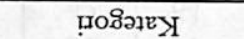 \\
\hline & & $\mathrm{g}$ & $\mathrm{g}$ & $\mathrm{g}$ & $\mathrm{g}$ & זִए!N \\
\hline & & SII & SI'8II & $\varepsilon Z^{i} L I I$ & $06^{6} 80 \mathrm{~L}$ & घ]EIDY \\
\hline \multirow[t]{2}{*}{ !ீ8రు! I } & $\mathrm{g}$ & $t I I$ & L9'LII & $\varepsilon \varepsilon^{6} 9 I I$ & $9 S^{\prime} 90 \mathrm{I}$ & घұЕІәу \\
\hline & & ZZOI & $6 \mathrm{SOI}$ & $\angle t 0 I$ & 696 & पеरणn! \\
\hline !ด & $\mathrm{q}$ & SZI & $9 Z \mathrm{Zl}$ & $\varepsilon Z I$ & LZI & LI Ịִng \\
\hline !ீ:ธిบ! & g & $\varepsilon I L$ & 6II & $8 \mathrm{II}$ & $\varepsilon Z I$ & 9I Ịִng \\
\hline 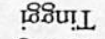 & g & 9II & $Z Z I$ & 6II & $\varepsilon 0 I$ & SI Ịִng \\
\hline surpas & כ & $\angle 6$ & tol & I0I & LOI & tI Ịִng \\
\hline ழீ8ిน!ు & q & IZI & IZI & $\varepsilon Z I$ & \8 & عI Iṇng \\
\hline ழீ8ిน!! & g & LOI & ZIL & ILI & $8 \mathrm{II}$ & ZI Ịִng \\
\hline 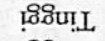 & g & tol & OLI & $60 \mathrm{I}$ & $\$ 6$ & II נִ̣ng \\
\hline ழிరిు!ు & q & 6II & $\nabla Z I$ & $Z Z I$ & ZIL & of Inng \\
\hline 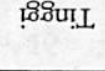 & g & 6II & IZI & IZI & SII & $\begin{array}{c}60 \text { mang } \\
\text { [euo!synnsuI yədsy }\end{array}$ \\
\hline \multirow[t]{2}{*}{ !88 } & $\mathrm{g}$ & 9II & $\varepsilon 9^{\circ} 8 \mathrm{LI}$ & EI'8IL & SZ'IIL & घีЕІә્ \\
\hline & & 826 & $6+6$ & St6 & 068 & पе|un / \\
\hline !ீ8บ!L & q & ZZI & SII & $9 Z I$ & $\nabla Z I$ & 8 Inng \\
\hline . surpas & כ & 86 & $00 \mathrm{~L}$ & ZOI & 26 & $L$ Inng \\
\hline ழீ8ิు! & g & $\varepsilon I L$ & $9 L I$ & $8 \mathrm{II}$ & †OL & 9 Inng \\
\hline ழீ8ిบ! & g & LII & OZI & OZI & III & ૬ Inng \\
\hline ழிవిบ! & g & $Z Z I$ & $\angle Z I$ & $8 \mathrm{LI}$ & $Z Z I$ & $\downarrow$ Inng \\
\hline !ீอిบ! & g & $0 Z I$ & $\nabla Z I$ & 9LI & IZI & $\varepsilon$ Iṇng \\
\hline \multirow{2}{*}{ 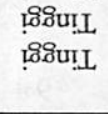 } & q & $\varepsilon L I$ & $Z Z I$ & $\varepsilon Z I$ & $\varepsilon 6$ & $\tau$ Ing \\
\hline & q & $\varepsilon Z I$ & SZI & ZZI & દZI & 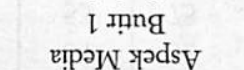 \\
\hline \multirow[b]{2}{*}{ रम्गएत्र } & & & 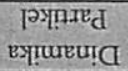 & 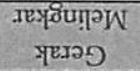 & $\begin{array}{l}\text { SninT } \\
\text { צשIכS }\end{array}$ & \multirow{2}{*}{$\begin{array}{l}\text { IsEnjeAa IP } \\
\text { gutré Yədsy }\end{array}$} \\
\hline & IEIN & घ઼ाગ્ય & & IOYS чथाün] & & \\
\hline
\end{tabular}

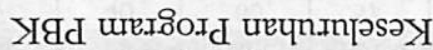

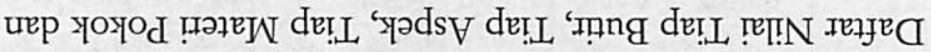
9 [PqE L

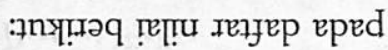

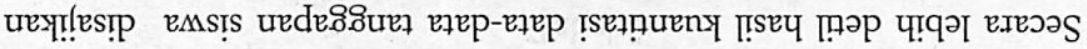


Dari tabel 6 diatas dapat dijelaskan sebagai berikut:

Penilaian Tiap Butir

Secara keseluruhan dari ketiga materi pokok, petunjuk penggunaan program dinilai tinggi artinya sudah jelas; teks/tulisan dalam program dinilai tinggi artinya sudah jelas terbaca; kualitas tampilan gambar dinilai tinggi artinya sudah bagus/menarik; suara/narasi didalam program dinilai tinggi artinya sudah bagus mutu rekamnya; daya dukung musik dinilai sedang artinya cukup menarik; navigasi didalam program dinilai tinggi artinya sudah lengkap sehingga user dapat menjelajah ke semua materi dengan nyaman; standar kompetensi dan kompetensi dasar dinilai tinggi artinya sudah jelas dimengerti; petunjuk belajar di dalam program dinilai tinggi artinya sudah jelas dapat dipahami; teks pada kalimat dinilai tinggi artinya teks pada kalimat mudah untuk dipahami; materi/ isi pelajaran dalam program juga mudah dipahami; urutan penyajian dalam program dinilai tinggi artinya urutan penyajian sudah tepat; latihan-latihan soal dalam program dinilai sedang artinya latihan-latihan soal sudah mencukupi; program dinilai interaktif; umpan balik/respon dinilai tinggi artinya umpan balik/respon sudah jelas; dan siswa merasa terbantukan belajarnya karena adanya program tersebut.

Penilaian Tiap Aspek

Ditinjau dari aspek media secara keseluruhan program PBK menarik (dinilai/dikategorikan tinggi) oleh responden. Ditinjau dari aspek pembelajaran, secara keseluruhan program PBK juga dinilai tinggi artinya jelas dimengerti oleh responden, dan mampu menumbuhkan motivasi belajar.

\section{Penilaian Tiap Materi}

Kualitas program pada materi Gerak Lurus, Gerak Melingkar, dan Dinamika Partikel ditinjau dari aspek pembelajaran dan aspek media diberi nilai B (tinggi). Kualitas program pada materi Gerak Melingkar ditinjau dari aspek-aspek yang sama diberi nilai B (tinggi). Kualitas program pada materi Dinamika Partikel diberi nilai B (tinggi). 
Penilaian Umum

Secara umum kualitas Program Pembelajaran Fisika SMA Berbantuan Komputer diberi nilai B (tinggi) oleh responden.

Kajian Produk Akhir

Walau belum sempurna, Program Pembelajaran Fisika Berbantuan Komputer ini memiliki beberapa keunggulan jika dibandingkan dengan program pembelajaran fisika yang beredar di pasaran. Keunggulannya antara lain program pembelajaran ini berbasis kurikulum, dan didesain dengan menggunakan kaidah-kaidah desain pembelajaran dan desain screen.

Ada beberapa hal yang menonjol menurut penilaian siswa pada program ini, yaitu adanya sajian animasi yang bervariasi. Adanya animasi membuat program PBK menjadi menarik dan disenangi. Membuat program yang disenangi dan menarik itu tidaklah mudah. Maka dari itu merupakan suatu kepuasan tersendiri bagi pengembang/peneliti bahwa karya/produk ini diterima oleh siswa. Artinya, tujuan pengembangan program PBK telah tercapai.

Ketertarikan siswa terhadap sumber belajar merupakan gejala yang sangat baik untuk menuju peningkatan hasil belajar. Sebagai guru, menciptakan ketertarikan siswa terhadap sajian-sajian pembelajarannya merupakan suatu keharusan, supaya siswa tetap termotivasi dalam belajar. Kreativitas seorang guru diuji, bagaimana cara menyuguhkan materi ajar yang menyenangkan dan menarik yang dapat menumbuhkan motivasi belajar. Program PBK ini tentu bisa menjadi pilihannya.

Program pembelajaran fisika berbantuan komputer ini sebetulnya didesairr untuk pembelajaran individual. Namun karena pada pelajaran fisika banyak terdapat istilah-istilah sulit, maka penyajian materi kepada siswa dengan menggunakan program ini tidak cukup hanya dilepas begitu saja siswa belajar sendiri. Guru harus terus melakukan penjelasan-penjelasan untuk membantu mempercepat pemahaman siswa. 


\section{Simpulan}

Dari hasil penelitian pengembangan ini, dapat disimpulkan sebagai berikut:

1. Program pembelajaran fisika SMA berbantuan komputer sebagai sumber belajar alternatif ditinjau dari aspek media dari ketiga materi pokok yang diujicobakan secara keseluruhan, dinyatakan menarik, berkualitas tinggi atau dinilai $B$ (tinggi) oleh responden, mampu memberikan motivasi belajar siswa. Ditinjau dari aspek pembelajaran dari ketiga materi pokok yang diujicobakan secara keseluruhan, juga dinyatakan berkualitas tinggi atau dinilai B (tinggi) oleh responden, siswa merasa terbantukan belajarnya karena adanya program tersebut.

2. Program pembelajaran fisika SMA berbantuan komputer sebagai sumber belajar alternatif, terbukti mampu menaikan skor rerata posttest siswa terhadap skor rerata pretest sebesar 18\%. Diharapkan apabila program dinilai menarik maka pemahaman siswa terhadap isi (materi) program juga meningkat.

\section{Daftar Pustaka}

Agnew, P. W., Kellerman, A. S., \& Meyer, J. M. (1996). Multimedia in the classroom. Needham Heights: Allyn \& Bacon, A Simon \& Schuster Company.

Andersen, H.O., \& Koutnik, P.G. (1972). Towvard more effective science instruction in secondary education. New York: The Macmillan Company.

Arief S. Sadiman, dkk. (1986). Media pendidikan. pengertian, pengembangan, dan pemanfaatannya. Jakarta: Pustekkom Dikbud.

Bhattacharya, M., Akahori, K., \& Kumar, K.L. (1999). Evaluation of a multimedia package on paedagogical design and display visual. International Journal of Educational Technology. Vol.1, No.1.

Borg, W. R., \& Gall, M.D. (1983). Educational research. An introduction. (Fourth Edition). White Plains: Longman Inc.

Criswell, E.L. (1989). The design of computer-based instruction. New York: Macmillan Publishing Company. 
Dwyer, Francis M. (1978). Strategies for improving visual learming. A Handbook for the effective selection design, and use of visualized materials. State College Pennsylvania: Learning Services.

Fresen, J. W. (1996) Random Variables: A CAI tutorial in statistics for distance education. A mini-dissertation Magister Education in Computer-Assisted Education in the Departement of Didactics of the Faculty of Education, University of Pretoria. Diambil pada tanggal 13 Maret 2004. Dari http://upetd.up.ac.za/thesis/ available/etd10192001-124625/unrestricted/.Kemp, J.E (1975). Planning \& producing audiovisual materials. (Third Edition). New York: Thomas Y. Crowell Company, Inc.

Kemp, J.E., \& Dayton, D.K. (1985). Planning and producing instructional media (Fifth Edition). New York: Harper \& Row, Publishers, Inc.

Prata, A., \& Lopes, P.F. How to plan, develop, and evaluate multimedia applications$A$ simple model. Diambil pada tanggal 21 Juli 2004 dari httpi// wwwesce.ips.pt/NOTICIAS/Invertig/artigos.pdf.

Simonson, M.R., \& Thomson, A. (1994). Educatonal computing foundations (Second Edition). New York: Macmillan College Publishing Company.

Walker, D.F., \& Hess, R.D. (1984). Instructional software. Principles and perspectives for design and use. Belmont: Wadsworth, Inc. 